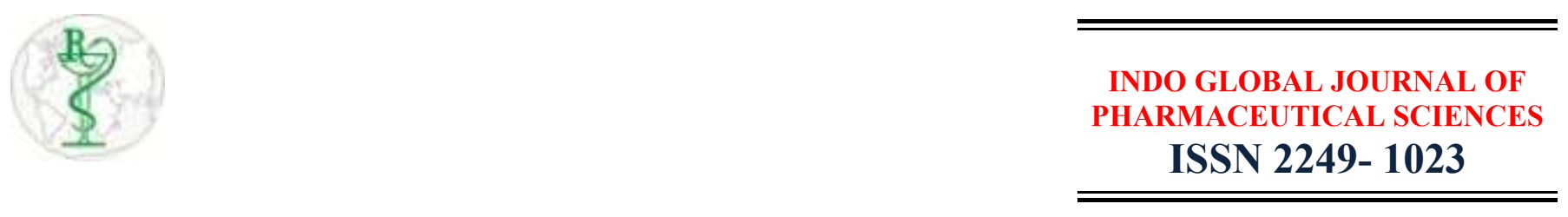

\title{
Lactic Acid Bacteria: Applications in Food and Health
}

\author{
Kashyapi Chakravarty, Smriti Gaur * \\ Department of Biotechnology, Jaypee Institute of Information Technology, Sector-62, Noida, U.P., India
}

Address for Correspondance: Smriti Gaur, smriti.gaur@jiiit.ac.in

Keywords Lactic Acid Bacteria; Indian Fermented Foods; Functional Foods; Probiotics.
ABSTRACT: Lactic acid bacteria constitute an integral part of fermented functional foods having numerous health benefits. Besides providing nutrition these bacteria also help in preservation of food, flavour induction and better digestibility through lactic acid fermentation. There are many Lactic Acid Bacteria which are yet to be explored for their beneficial properties. Therefore, these microorganisms require extensive study to gauge their utility in diverse areas. A plethora of traditional Indian fermented foods have been explored wherein lactic acid bacteria play an important role. This group of bacteria is also used in food industry majorly as starter cultures. The most promising usage of lactic acid bacteria is in the production of probiotics that are viable microbial cells providing health benefits to the host upon consumption. There has been an increase in the awareness among masses about the beneficial effects of consumption of fermented foods rich in lactic acid bacteria. Hence, extensive research on new strains of lactic acid bacteria, their functionality and large scale production is the need of the hour in order to cater to the growing number of consumers. This review aims to discuss the significance of lactic acid bacteria in traditional Indian fermented foods and food industry as well as some of their major health benefits. (C) 2016 iGlobal Research and Publishing Foundation. All rights reserved.

Conference Proceedings: International Conference on Advances in Plant and Microbial Biotechnology (PMB2017); JIIT, Noida: February 02-04, 2017

Indo Global Journal of Pharmaceutical Sciences( ISSN 22491023 ; CODEN- IGJPAI; NLM ID: 101610675) indexed and abstracted in EMBASE(Elsevier), SCIRUS(Elsevier),CABI, CAB Abstracts, Chemical Abstract Services(CAS), American Chemical Society(ACS), Index Copernicus, EBSCO, DOAJ, Google Scholar and many more. For further details, visit http://iglobaljournal.com 